\title{
Pohjoisen ekokritiikin vakuuttavaa esittelyä
}

\author{
Reinhard Hennig, Anna-Karin Jonasson \& Peter Degerman (toim.) 2018: Nordic \\ Narratives of Nature and the Environment: Ecocritical Approaches to Northern \\ European Literatures and Cultures. Lanham, MD: Lexington Books. $252 \mathrm{~s}$.
}

Ekokritiikki on ollut 1990-luvulta alkaen kasvava ja monipuolistuva tutkimussuuntaus, joka on 20l0-luvulle tultaessa laajentanut aineistonsa kaikenlaisiin kulttuurisiin esityksiin erilaisissa maantieteellisissä olosuhteissa ja saanut pitävän jalansijan myös Pohjoismaissa. Pohjoismaista aineistoa on kuitenkin tutkittu ekokritiikin näkökulmista lähinnä pohjoismaisilla kielillä, eikä pohjoismainen ekokritiikki näin ollen ole ollut saavutettavissa laajemmalle kansainväliselle yleisölle. Artikkelikokoelma Nordic Narratives of Nature and the Environment. Ecocritical Approaches to Northern European Literatures and Cultures on ensimmäinen englanninkielinen esitys pohjoismaiseen kirjallisuuteen ja kulttuuriin keskittyvästä ekokritiikistä ja tervetullut avaus ekokritiikin kansainvälisellä kentällä. Teoksen taustalla vaikuttaa 2016 perustettu tutkimusverkosto Ecocritical Network for Scandinavian Studies (ENSCAN), joka on kansainvälinen yhteistyöväylä Pohjoismaiden parissa työskenteleville ekokritiikin alan tutkijoille. Ekokritiikin kulttuurintutkimuksellinen luonne havainnollistuu hyvin viidentoista kirjoittajan panoksesta syntyneen teoksen artikkeleissa, joissa kaunokirjallisuuden lisäksi tarkastellaan esimerkiksi elokuvaa, valokuvataidetta, videoinstallaatioita ja ei-fikitiivisiä tekstejä.

Pohjoismaista kehystä esittelevässä johdannossa teoksen toimittajat Reinhard Hennig,Anna-Karin Jonasson ja Peter Degerman tuovat esiin, että Pohjoismaihin liittyy kansainvälisissä mielikuvissa erityinen vihreys, käsitys alueen ympäristötietoisuudesta ja ansioituneisuudesta ympäristönsuojelua koskevissa asioissa. Toimittajat kuitenkin huomauttavat, että näkemykselle Pohjoismaiden vihreydestä ei todellisuudessa ole nykypäivänä vahvaa näyttöä, sillä viimeaikaiset tutkimukset ovat osoittaneet Pohjoismailla olevan paljon parannettavaa esimerkiksi maatalouden, energiatehokkuuden, ekosysteemien suojelun ja varsinkin kulutuksen saralla. Toimittajien mukaan luonnon ja ympäristön tarkasteleminen erilaisissa pohjoismaisissa kulttuurisissa esityksissä voi tarjota kriittisiä näkökulmia siihen, miten vallitseva käsitys Pohjoismaiden erityisestä luontosuhteesta on päässyt historiallisesti kehittymään.

Ekokriittiselle tutkimukselle on 90-luvulta alkaen versonut erilaisia painopisteitä, jotka hyvin havainnollistuvat teoksen monipuolisissa artikkeleissa. Luonnontieteessä ristiriitaisen vastaanoton saanut uuteen, ihmisen läpikotaisesti muovaamaan geologiseen eepokkiin viittaava antroposeeni (anthropocene) on viime vuosikymmeninä vakiintunut ekokriittisen kirjallisuudentutkimuksen käsitteeksi, ja se jäsentääkin teoksen ensimmäistä osiota, joka tarkastelee pohjoisia antroposeenin narratiiveja. Mielenkiintoisen tulokulman pohjoisen antroposeeniin tarjoaa esimerkiksi 
Lauren E. LaFaucin artikkeli "The Safest Place on the Earth: Cultural Imaginaries of Safety in Scandinavia", joka tarkastelee mielikuvaa pohjoisesta seudusta turvallisena paikkana biologisen ja kulttuurisen tiedon säilyttämiseen. LaFauci lähestyy aihetta analysoimalla Huippuvuorten siemenholvin siemenpankkia, jonka tarkoituksena on varmistaa kasvien siementen saatavuus globaalin kriisin varalta, ja Oslon The Future Library Project -hanketta, jossa valitaan joka vuosi yhdeltä maailman kirjailijalta talteen teoksen pituinen käsikirjoitus sadan vuoden ajan vuosina 20I4-2II4. Hankkeen tavoitteena on tuottaa edustava antologia maailman kirjallisuudesta ja säilyttää kieliä, jotka mahdollisesti eivät enää sadan vuoden päässä ole elinvoimaisia. LaFauci tuo esiin, kuinka näiden hankkeiden kautta Skandinavia näyttäytyy antroposeenin aikana stabiilina suhteessa ilmastonmuutoksen myrskyihin sekä ilmastonmuutoksen väistämättä aiheuttamiin yhteiskunnallisiin kriiseihin ja turvallisena paikkana säilyttää valtavaa määrää maailman biologista ja kulttuurista perintöä. LaFauci kuitenkin kyseenalaistaa Skandinavian stabiiliuden ja nostaa esiin kysymyksen siitä, kenen kannalta alue lopulta on stabiili. Artikkeli havainnollistaa hyvin, kuinka moninaisia kulttuurisia ilmiöitä ekokriittisen kirjallisuudentutkimuksen tutkimuskohteet ja antroposeeniin kytkeytyvät ilmiöt voivat olla.

Ekokritiikin neljänneksi aalloksi on kutsuttu niin sanottua materiaalista ekokritiikkiä, jossa fokukseen nousevat ympäristöllisten asioiden, paikkojen, prosessien, voimien ja kokemusten pohjalla oleva materiaalisuus ja materian elävyys. Materiaalisen ekokritiikin myötä on herännyt myös uudenlainen kiinnostus ekopoeettiseen kieleen, yhteen materian ulottuvuuteen. Materiaalinen ja kieliorientoitunut ekokritiikki saavat sijaa varsinkin teoksen toisessa osiossa "Language, Aesthetics, and the Non-human in Nordic Environments", joka korostuu teoksessa erityisen ansiokkaana ja innovatiivisena. Esimerkiksi osastoon kuuluva Beatrice M. G. Reedin artikkeli laajentaa ekokriittisen analyysin tropologiaa lanseeraamalla kentälle käsitteen ekomorfismi (ecomorphism), jolla eräänlaisena antropomorfismin vastinparina tarkoitetaan luonnon tai ekologian alaan kuuluvien ominaisuuksien siirtämistä inmiseen kuvallisella tasolla. Reedin käsite avaa kiitollisesti uusia tulokulmia ekokriittiseen ja ekoretoriseen analyysiin. Ihmisten ja kasvien vuorovaikutusta suomalaisessa tämän päivän dystopiakirjallisuudessa analysoivan Hanna Samolan artikkeli puolestaan nostaa kiinnostavasti esiin kriittisen kasvitutkimuksen ja sen annin ihmisen erityisaseman purkamiselle ja ei-inhimillisen agentiivisuuden tarkastelulle.

Teoksen viimeisessä osiossa etualalla ovat ympäristöoikeus ja postkolonialistinen pohjoinen: tässä osiossa esiin nousee pohjoiseen postkolonialismiin essentiaalisesti liittyvä saamelaiskehys. Osiossa erityisen antoisa on Cheryl J. Fishin artikkeli, joka tarkastelee kahden saamelaistaiteilijan, Sami Liselotte Wajstedtin ja Marja Helanderin elokuvaa ja valokuvataidetta vastauksena kaivosteollisuuden, pohjoismaisten valtioiden ja yritysten tavoille hyväksikäyttää Saamenmaata. Kehittämänsä elegisen eko-oikeuden (elegic ecojustice) käsitteen kautta ja feminististä näkökulmaa soveltaen Fish tarkastelee, kuinka nämä saamelaistaiteili- 
jat haastavat perinteisiä käsityksiä subliimista ja kulttuurisia näkemyksiä ympäristöstä. Fish yhdistää mielenkiintoisesti elegian konseptia elokuvan ja valokuvataiteen ympäristösuhteen tarkasteluun ja eko-oikeudelliseen ajatteluun.

Nordic Narratives of Nature and the Environment. Ecocritical Approaches to Northern European Literatures and Cultures on kaikkinensa kunnianhimoinen ja onnistunut esitys pohjoismaisesta ekokritiikistä ja vakuuttavaa antia ekokritiikin kansainväliselle tutkimuskentälle. Samalla teos valottaa hyvin pohjoismaista kirjallisuutta ja kulttuuria englanninkieliselle yleisölle. Teoksen monipuoliset sisällöt takaavat, että jokainen ekokritiikistä kiinnostunut saa kokoelmasta jotakin itselleen.

\section{Kirjoittaja}

Reeta Holopainen, FM, tutkijakoulutettava, kotimainen kirjallisuus, Helsingin yliopisto, reeta.holopainen@helsinki.fi 